\title{
Tomato Plants Transformed with the Inhibitor-of-Virus-Replication Gene Are Partially Resistant to Botrytis cinerea
}

\author{
Gad Loebenstein, Dalia Rav David, Diana Leibman, Amit Gal-On, Ron Vunsh, Henryk Czosnek, and Yigal Elad
}

First, second, third, fourth, and seventh authors: Department of Plant Pathology and Weed Research, Agricultural Research Organization, The Volcani Center, Bet Dagan 50250; fifth author: Evogene Ltd. P.O.B. 2100, Rehovot 76121; and sixth author: The Smith Faculty of Agriculture, Food and Environment, The Hebrew University of Jerusalem, Rehovot 76100, Israel. Accepted for publication 17 October 2009.

\begin{abstract}
Loebenstein, G., Rav David, D., Leibman, D., Gal-On, A., Vunsh, R., Czosnek, H., and Elad, Y. 2010. Tomato plants transformed with the inhibitor-of-virus-replication gene are partially resistant to Botrytis cinerea. Phytopathology 100:225-229.

Tomato plants transformed with a cDNA clone encoding the inhibitorof-virus-replication (IVR) gene were partially resistant to Botrytis cinerea. This resistance was observed as a significant reduction in the size

of lesions induced by the fungus in transgenic plants compared with the lesions on the nontransgenic control plants. This resistance was weakened when plants were kept at an elevated temperature, $32^{\circ} \mathrm{C}$, before inoculation with $B$. cinerea compared with plants kept at 17 to $22^{\circ} \mathrm{C}$ prior to inoculation. Resistance correlated with the presence of IVR transcripts, as detected by reverse transcription-polymerase chain reaction. This is one of the few cases in which a gene associated with resistance to a virus also seems to be involved in resistance to a fungal disease.
\end{abstract}

The local lesion response in tobacco cultivars containing the $\mathrm{N}$ gene, one of the most striking resistance phenomena, has been associated with the presence of a protein with antiviral properties named inhibitor-of-virus-replication (IVR) $(1,2,11-13,20,21,27)$. Transformation of susceptible Nicotiana tabacum cv. Samsun nn plants with the IVR-encoded NC330 clone driven by the Cauliflower mosaic virus $35 \mathrm{~S}$ promoter resulted in the expression of variable resistance to both Tobacco mosaic virus (TMV) and Botrytis cinerea in a number of plants. However, even in the most resistant lines, resistance to TMV and $B$. cinerea was variable among self-crossing progenies, even after four generations, and not all of the plants were resistant (2).

Gray mold caused by $B$. cinerea is an important disease of numerous greenhouse and field crops throughout the world and infects many vegetable, ornamental, and horticultural species $(5,6,9)$. It attacks flowers, fruits, leaves, and stems of tomato plants grown in greenhouses. The pathogen primarily infects leaves, but lesions are also found on the stems of infected plants $(5,6,25)$. This disease is a major problem everywhere tomatoes are grown in high-wire cropping systems and it is often the reason why a crop is harvested earlier than planned. The disease also regularly causes losses in unheated and partially heated crops grown in Israel during the winter $(24,26)$. Chemical control remains an important means of managing gray mold, although it is impeded by the development of pathogen resistance. Site-specific benzimidazole, dicarboximide, and $\mathrm{N}$-phenylcarbamate fungicides have been used intensely since the early 1970s, and this use has led to the rapid selection of resistant strains of fungal pathogens in Israel and other countries $(8,19)$. In recent years, some new botryticides with different modes of action have been introduced worldwide and in Israel. However, Korolev et al. (18) found resistance to the new botryticides, fenhexamid, fludioxonil, and pyrimethanil, in populations of $B$. cinerea. Studies in various crops have yielded a wide range of information regarding the

Corresponding author: G. Loebenstein; E-mail address: Gad-talma@barak.net.il

doi:10.1094/PHYTO-100-3-0225

(C) 2010 The American Phytopathological Society conditions that promote $B$. cinerea infection in greenhouse crops (4). The temperature range for gray mold development in greenhouse crops is 12 to $30^{\circ} \mathrm{C}$ (16), with an optimal range of 15 to $20^{\circ} \mathrm{C}$; although the pathogen is active even at temperatures as low as $0^{\circ} \mathrm{C}(8,9)$. Initial infection occurs on live or dead plant tissue (5). Programs for breeding resistance to $B$. cinerea are in progress and partial resistance has been identified in accessions of wild relatives of tomato, such as Solanum habrocha (10), as well as in transgenic tomatoes expressing a wheat oxalate oxidase (29). To date, none of these resistant lines have reached commercial fields.

IVR inhibited virus replication in protoplasts derived from both local lesion-responding resistant Samsun NN and systemically responding susceptible $N$. tabacum cv. Samsun nn plants. IVR has also been obtained from the intracellular fluid of hypersensitive tobacco leaves infected with TMV and from induced-resistant tissue (1). A cDNA (NC330) was isolated from an expression library prepared from induced-resistant (uninfected) leaf tissue of Samsun NN. The NC330 expressed a $21.6 \mathrm{kDa}$ IVR-like protein in $E$. coli that was recognized by an IVR antibody, which exhibited antiviral properties in biological tests (1). Here, we report that transformation of tomato plants with the IVR-encoding NC330 cDNA resulted in strong resistance to $B$. cinerea. This may be a first step toward the development of tomato plants that are resistant to $B$. cinerea.

\section{MATERIALS AND METHODS}

Plant transformation. The tomato (Solanum lycopersicum) cv. VF36 was used in this study. This tomato cultivar is not a commercial variety, but it was found to be very suitable for transformation (22). Tomato cv. VF36 seeds were germinated on Nitsch medium (24). Cotyledon explants were excised from 10-day-old seedlings, cut from both sides (proximal and distal, 2/3 of the cotyledon remaining), and cultured overnight on a 1-day-old feeder layer consisting of $3 \mathrm{ml}$ of a 7-day-old tobacco suspension culture, plated on Murashige and Skoog (MS) agar medium and overlaid with sterile Whatman filter paper. Agrobacterium tumefaciens strain EHA 105, containing the binary vector pGA 492 with the IVR gene (the cDNA clone of tobacco origin), was 
grown overnight in $2 \times$ YT medium containing rifampicin (30 $\mathrm{mg} / \mathrm{liter})$, kanamycin $(50 \mathrm{mg} / \mathrm{liter})$, and tetracycline $(10 \mathrm{mg} / \mathrm{liter})$ and diluted to optical density at $600 \mathrm{~nm}\left(\mathrm{OD}_{600 \mathrm{~nm}}\right)=0.3$ with $\mathrm{MS}$ medium. Acetosyringone $(100 \mu \mathrm{M}$, final concentration), was added to the diluted bacterial suspension. Cotyledons were submerged in the bacterial suspension for 15 to $30 \mathrm{~min}$, and then blotted on sterile Whatman No. 1 paper and placed back on the feeder plates for $45 \mathrm{~h}$ co-cultivation in the dark. The explants were then transferred to selective regeneration medium (solidified MS medium minerals (23) with Nitsch vitamin medium containing carbenicillin [400 mg/liter], kanamycin [70 mg/liter], and zeatin [1 mg/liter]) (23). Regenerated explants were transferred to the same fresh medium biweekly. Green shoots, 1 to $3 \mathrm{~cm}$ tall, were separated from calli and transferred to Nitsch medium containing carbenicillin (150 mg/liter), kanamycin (50 mg/liter), and indole butyric acid ( $1 \mathrm{mg} / \mathrm{liter}$ ). Five rooted plants (T0) were transplanted to soil and transferred to a greenhouse. These five plants were allowed to flower and their offspring (T1) were screened for the presence of the IVR gene.

Verification of the presence of the IVR gene. Polymerase chain reaction (PCR) was used to evaluate the presence of the NPTII and NC300 genes. Specific primers were used. Among the offspring of NC, 4 to 5 plants out of 10 tested positive for both NPTII and NC300. Among the offspring of NC, 3 to 5 plants out of 10 contained both genes. IVR expression was evaluated using reverse transcription (RT)-PCR. A good correlation was observed between the lines that tested positive for the presence of the genes in the PCR analysis and those testing positive in the RT-PCR analysis (Fig. 1). The plants that tested positive for the gene in the PCR analysis were allowed to flower and daughter plants (T2) were raised from their seeds and tested for resistance to $B$. cinerea. Subsequently, we tested for resistance to $B$. cinerea among three additional generations of self-crossed, resistant plants derived from the initial transformants.

Botrytis infection and disease evaluation. $B$. cinerea (isolate BcI16) (14) was cultured on potato dextrose agar (Difco Laboratories, Detroit, MI) in petri dishes incubated at $20^{\circ} \mathrm{C}$. Conidia were harvested from 14-day-old cultures by agitating small pieces of agar, bearing mycelia and conidia, in a glass tube. The suspension was then filtered through cheesecloth. The concentration of conidia was determined using a hemacytometer and adjusted to $5 \times 10^{5}$ cells $\mathrm{ml}^{-1}$. Glucose $(0.1 \%)$ was added to the final aqueous conidial suspension, together with $0.1 \% \quad \mathrm{KH}_{2} \mathrm{PO}_{4}$. Ten leaflets were removed from each tomato plant, placed on a tray and inoculated with 10- $\mu$ l drops of the conidial suspension ( 2 drops per leaflet). Following inoculation, the trays were covered with plastic and incubated at $20^{\circ} \mathrm{C}$ and $95 \%$ relative humidity, with $12 \mathrm{~h}$ of illumination each day. A similar procedure was followed with whole plants. Ten leaves on each whole tomato

\section{A}

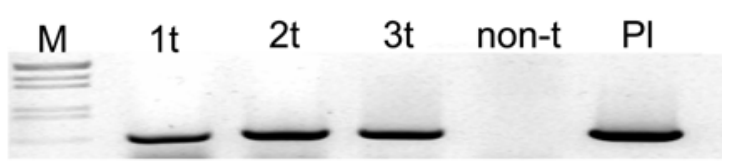

B
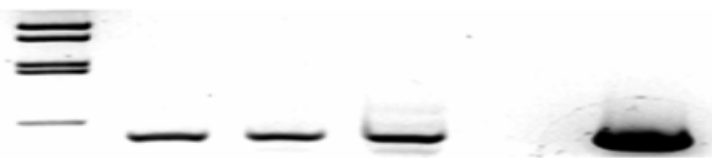

Fig. 1. Detection of inhibitor-of-virus-replication transgene in transformed plants by polymerase chain reaction (PCR) and confirmation of the transcription of the transgene by reverse transcription (RT)-PCR. Total DNA and RNA from three transgenic plants $(1 \mathrm{t}, 2 \mathrm{t}$, and $3 \mathrm{t}$ ) from line NC3 were used as templates for A, PCR and $\mathbf{B}$, RT-PCR analyses. The NC330 plasmid (P1) served as a positive control and genetic material from nontransgenic plants (non-t) was used as a negative control. plant were inoculated as described for the detached leaflets. The severity of the resultant necrotic lesions was determined according to the scale described below. The diameter of a 10- $\mu$ l drop on a tomato leaf was $5 \mathrm{~mm}$, corresponding to an area of $19.6 \mathrm{~mm}^{2}$. Disease developed gradually and was first visible 3 to 5 days after inoculation. The first symptoms were small necrotic lesions that covered only part of the area originally covered by the drop of the $B$. cinerea suspension. The diameter of a $B$. cinerea lesion on a typical tomato leaf at 9 to 10 days after inoculation was approximately $9 \mathrm{~mm}$, corresponding to an area of $63.5 \mathrm{~mm}^{2}$. A $12-\mathrm{mm}-$ diameter lesion (corresponding to an area of $113 \mathrm{~mm}^{2}$ ) was used as a reference point and assigned a value of $100 \%$. A pictorial scale of lesion sizes was used, including the following relative sizes: $0,1,2,5,10,20,40,75$, and $100 \%$. Lesion size (a measure of disease severity) was determined for each lesion using this pictorial scale (12). Disease reduction was calculated according to the formula: $100-100 \times \mathrm{A} / \mathrm{B}$, in which $\mathrm{A}=$ disease level in the treatment and $\mathrm{B}=$ disease level in the untreated control.

Statistical analyses. Data in percentages were arcsine-transformed before further analysis. Disease severity and the calculated area under disease progress curve (AUDPC) data were analyzed using analysis of variance and Fisher's protected least significant difference test. The statistical analyses were conducted using JMP software (SAS Institute, Cary, NC).

\section{RESULTS}

Disease evaluation in IVR-transformed and control plants. Marked resistance to $B$. cinerea was observed in several of the transgenic T2 lines. In a preliminary experiment with detached leaflets from transgenic NC5 tomato plants, the severity of the disease reached $3.0 \%$. Meanwhile, in nontransgenic control plants, disease severity was $17.4 \%$ ( $82.7 \%$ disease reduction). In another experiment with detached leaflets, the AUDPC 6 days after inoculation was $62.9 \% \times$ days in nontransgenic control plants; whereas in the transgenic plants, it was $29.0 \% \times$ days $(53 \%$ disease reduction). When whole plants were tested between 30 and $50 \%$ of the plants of two lines showed significant resistance to $B$. cinerea. In parallel experiments, a good correlation was found between disease severity at 6 days after inoculation (average $1.0 \%$ compared with $40.7 \%$ in the nontransgenic control) and the presence of the IVR sequence as detected by PCR and RT-PCR (Fig. 1).

TABLE 1. Severity of Botrytis cinerea infection on leaves of inhibitor-ofvirus-replication-transformed tomato plants ${ }^{\mathrm{z}}$

\begin{tabular}{lrrrr}
\hline & \multicolumn{3}{c}{ Evaluation time dpi } & \\
\cline { 2 - 3 } Tomato line & 2 & 4 & 6 & AUDPC \\
\hline 6 May 2007 experiment & & & & \\
Control & 10.0 & 20.0 & $40.0 \mathrm{a}$ & $160.0 \mathrm{a}$ \\
NC3-3 & 0.4 & 5.6 & $15.7 \mathrm{bc}$ & $49.1 \mathrm{c}$ \\
NC3-6 & 2.1 & 6.1 & $9.9 \mathrm{c}$ & $43.6 \mathrm{c}$ \\
NC5-3 & 5.2 & 10.5 & $12.9 \mathrm{c}$ & $65.0 \mathrm{bc}$ \\
NC5-7 & 1.1 & 15.0 & $16.0 \mathrm{bc}$ & $76.0 \mathrm{bc}$ \\
NC5- & 2.5 & 4.0 & $25.1 \mathrm{~b}$ & $68.3 \mathrm{bd}$ \\
NC5-9 & 4.5 & 15.4 & $15.4 \mathrm{bc}$ & $82.4 \mathrm{~b}$ \\
8 July 2007 experiment & & & & \\
Control & 24.1 & $63.7 \mathrm{a}$ & & $84.9 \mathrm{a}$ \\
NC3-75 & 23.6 & $36.8 \mathrm{~b}$ & & $89.6 \mathrm{~b}$ \\
NC5-77 & 20.0 & $49.6 \mathrm{~b}$ & & $86.9 \mathrm{~b}$ \\
NC5-78 & 23.7 & $39.4 \mathrm{~b}$ & & $62.8 \mathrm{c}$ \\
NC5-85 & 18.8 & $25.1 \mathrm{c}$ & & $76.3 \mathrm{c}$ \\
NC5-86 & 20.3 & 35.6 & & \\
\hline
\end{tabular}

${ }^{\mathrm{z}}$ Plants were inoculated with a $5 \times 10^{5}$ cells $\mathrm{ml}^{-1}$ suspension supplemented with $0.1 \%$ glucose and $0.1 \% \mathrm{KH}_{2} \mathrm{PO}_{4}$. Disease severity is expressed as percentage of symptomatic leaf area, area under disease progress curve (AUDPC, days $\times \%$ symptomatic leaf area). Numbers in columns followed by a common letter are not significantly different according to Fisher's protected least significant difference test. 
Representative results from several T2 lines are summarized in Table 1 and results from an additional experiment are presented in Figure 2. A marked decrease in disease severity was observed in almost all of the transgenic plants (Table 1; Fig. 2). By 2 weeks after inoculation, the control nontransgenic plants had lost all of their leaves and died, while many of the transgenic plants were still alive (Fig. 3). One of the transgenic plants survived for a full month after inoculation. Resistance to $B$. cinerea in the three subsequent generations was only partial and did not exceed $50 \%$ of the plants.

Sensitivity of resistance to a higher temperature. In additional experiments conducted during the summer, when greenhouse temperatures reached $30^{\circ} \mathrm{C}$ and more, no resistance to $B$. cinerea was observed. Following this observation, controlled experiments were performed to evaluate resistance in transgenic tomato at a higher temperature, in comparison to resistance in plants kept at lower temperatures.

Four to five weeks after transplanting, transgenic and nontransgenic control tomato plants were kept at $32^{\circ} \mathrm{C}$ for 10 to 12 days before being inoculated with $B$. cinerea. Control plants were kept at 17 to $22^{\circ} \mathrm{C}$ before inoculation. As shown in Table 2, the transgenic plants that were kept in a cooler environment were resistant to $B$. cinerea, while the level of resistance was markedly

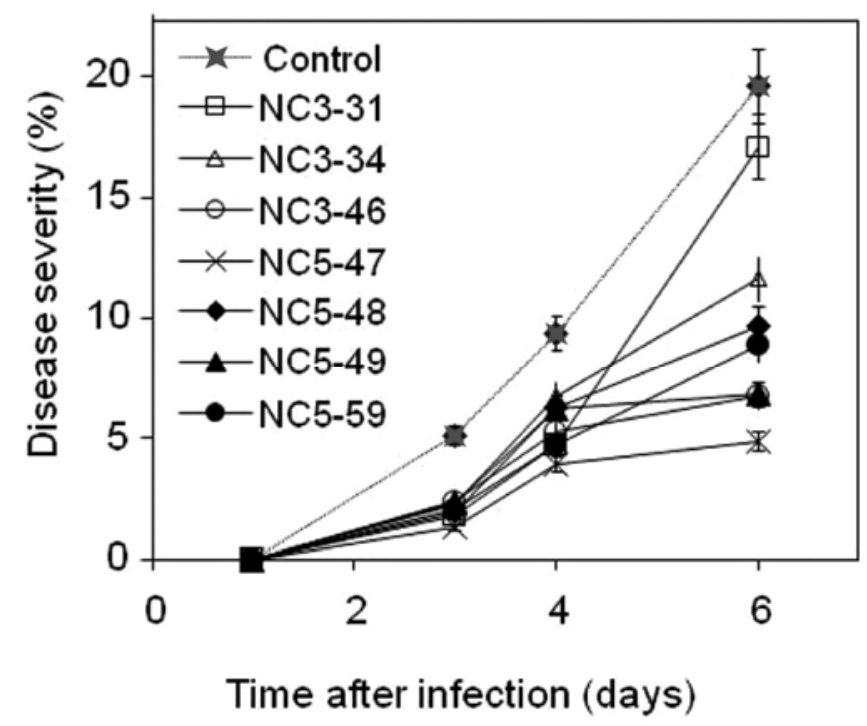

Fig. 2. Severity of disease caused by Botrytis cinerea on transgenic and nontransgenic (control) tomato plants (experiment performed 2 June 2007). reduced in the plants kept at the higher temperature. Similarly, nontransgenic plants that were incubated at the higher temperature were significantly more susceptible to the disease later on. Disease reduction due to the presence of the IVR gene was 46.0 to $73.1 \%$ after incubation at 17 to $22^{\circ} \mathrm{C}$ and much lower (32.6 to $40.0 \%$ ) in the plants that had been previously incubated at $32^{\circ} \mathrm{C}$ (Table 2).

In an additional experiment, uninfected transgenic and nontransgenic tomato plants were kept at 32 and $22^{\circ} \mathrm{C}$ to evaluate the effect of temperature on IVR expression. As shown in Figure 4,

TABLE 2. Effect of preincubation temperature on severity of disease caused by Botrytis cinerea on inhibitor-of-virus-replication (IVR)-transformed tomato plants evaluated 10 days after the differential temperature incubation $^{2}$

\begin{tabular}{|c|c|c|c|c|c|}
\hline $\begin{array}{l}\text { Temperature } \\
\text { during } \\
\text { incubation } \\
\text { without } \\
\text { pathogen }\end{array}$ & $\begin{array}{l}\text { IVR } \\
\text { pres- } \\
\text { ence }\end{array}$ & $\begin{array}{c}\text { Disease } \\
\text { severity at } \\
\text { day } 10(\%)\end{array}$ & $\begin{array}{c}\text { Disease } \\
\text { reduction } \\
\text { by IVR } \\
\text { presence } \\
(\%)\end{array}$ & $\begin{array}{c}\text { AUDPC } \\
\text { during days } \\
0 \text { to } 10 \\
(\% \times \text { days })\end{array}$ & $\begin{array}{c}\text { Disease } \\
\text { reduction } \\
\text { by IVR } \\
\text { presence } \\
(\%)\end{array}$ \\
\hline \multirow[t]{2}{*}{$17-22^{\circ} \mathrm{C}$} & - & $41.4 \pm 4.9 \mathrm{~b}$ & & $139.0 \pm 7.0 \mathrm{~b}$ & \\
\hline & + & $11.2 \pm$ & 73.1 & $33.5 \pm 6.0 \mathrm{c}$ & 76.0 \\
\hline \multirow{2}{*}{$30-35^{\circ} \mathrm{C}$} & - & $65.2 \pm 3.1 \mathrm{a}$ & & $228.8 \pm 6.4 \mathrm{a}$ & \\
\hline & + & $44.6 \pm 3.5 b$ & 32.6 & $137.2 \pm 14.6 \mathrm{~b}$ & 40.0 \\
\hline
\end{tabular}

z Plants were incubated at $20 \pm 1{ }^{\circ} \mathrm{C}$ and $95 \pm 3 \%$ relative humidity. Treatments in each column followed by the same letter are not significantly different according to Fisher's protected least significant difference test. + and - indicate the presence or absence of the IVR gene as determined using polymerase chain reaction.

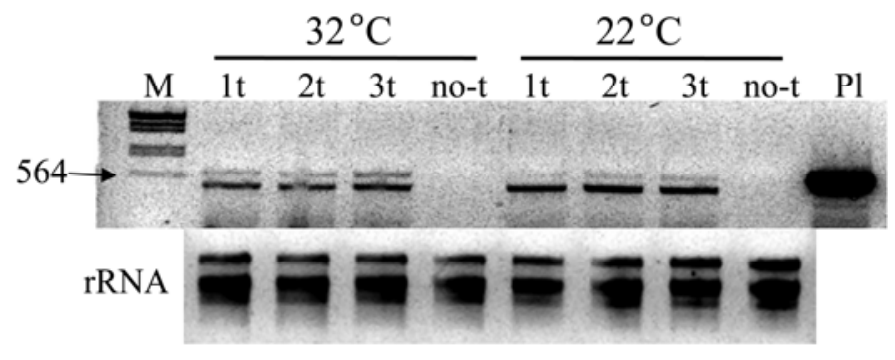

Fig. 4. Expression of the IVR transgene in tomato plants kept for 8 days at 22 or $32^{\circ} \mathrm{C}$. Total RNA was extracted from transgenic tomato plants 3 weeks after their germination (1t, 2t, and $3 \mathrm{t}$ ). The RNA samples (three from each temperature treatment) served as templates for RT-PCR analysis. The NC330 plasmid $(\mathrm{Pl})$ was used as a positive control and genetic material from nontransgenic tomato plants (non-t) was used as a negative control. $\mathrm{M}$ indicates molecular markers.

\section{Transgenic Nontransgenic controls}

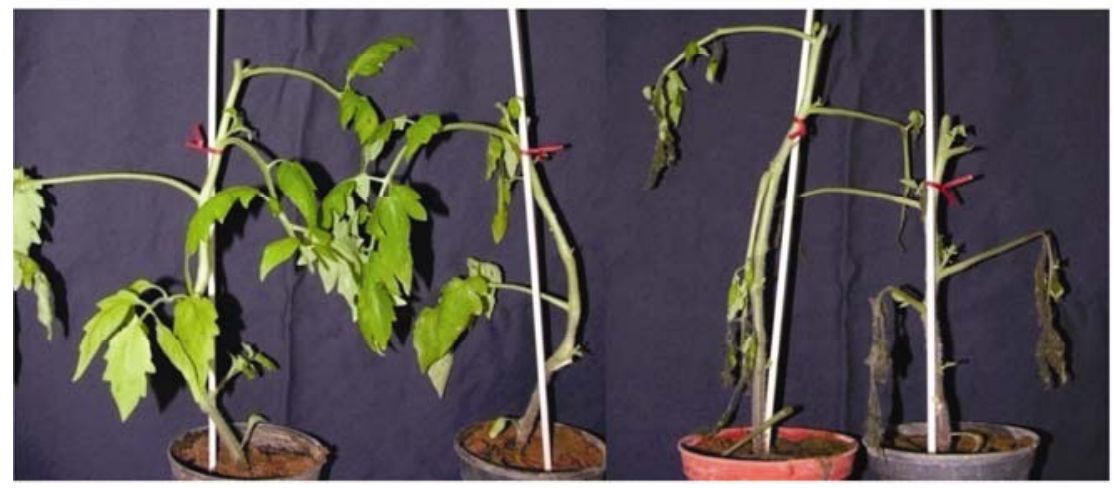

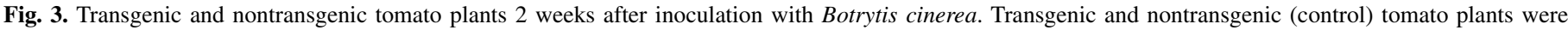

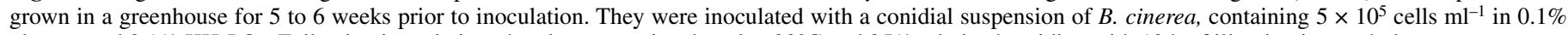
glucose and $0.1 \% \mathrm{KH}_{2} \mathrm{PO}_{4}$. Following inoculation, the plants were incubated at $20^{\circ} \mathrm{C}$ and $95 \%$ relative humidity, with $12 \mathrm{~h}$ of illumination each day. 
RT-PCR clearly detected IVR transcript expression in the uninfected transgenic tomato plants kept at the different temperatures $\left(22\right.$ and $\left.32^{\circ} \mathrm{C}\right)$. Similar data were obtained using semiquantitative RT-PCR (data not shown). Therefore, we can conclude that the exposure of the transgenic plants to high temperatures before their inoculation did not lead to depletion of the IVR mRNA.

\section{DISCUSSION}

We reported previously that tobacco plants transformed with a cDNA clone encoding an IVR-like protein were partially resistant to TMV and $B$. cinerea (2). Using an antibody raised against recombinant IVR, we were able to detect this protein in transgenic plants. However, we did not detect the protein in the control plants. TMV resistance was suppressed when the transgenic plants were kept at 32 to $34^{\circ} \mathrm{C}(2)$. Similarly, the production of IVR by infected protoplasts and by intact Samsun NN plants was almost completely suppressed at $35^{\circ} \mathrm{C}$ (11).

Transformation of tomato plants with the IVR gene also resulted in resistance to $B$. cinerea. In the future, this approach may become a useful tool for breeding resistant tomato cultivars. As with IVR-transformed tobacco, the observed resistance was only partial and did not exceed $50 \%$ of the plants. A similar variation in resistance levels has also been observed in transgenic Arabidopsis plants expressing a gene that increases tolerance to drought and salt stress (17). The lesions on the transgenic tomato plants were significantly smaller than those on the nontransgenic control plants. Similar to the IVR-transformed tobacco, the resistance in the transformed tomato plants was also sensitive to higher temperatures. When plants were kept at $32^{\circ} \mathrm{C}$ before they were inoculated, their resistance was markedly reduced, though not abolished. Although B. cinerea is sensitive to temperature and exposure of cucumber plants to temperatures as high as $30^{\circ} \mathrm{C}$ prior to their infection has been shown to result in more severe disease (7), the IVR-transgenic tomatoes exposed to temperatures of 30 to $36^{\circ} \mathrm{C}$ were still partially resistant (Table 2). When plants were kept at $20^{\circ} \mathrm{C}$ following inoculation with $B$. cinerea, the resistance mechanism was reactivated, though only to a limited extent. The sensitivity of the resistance to high temperatures resembles the behavior of TMV in hypersensitive tobacco. In that case, the virus moves systemically when plants are subjected to temperatures above $30^{\circ} \mathrm{C}$; while at lower temperatures, the virus remains localized within the lesion area. Transferring uninfected transgenic tomatoes to the warmer environment did not inhibit the transcription of the gene, as observed by RTPCR. Apparently, it is one or more of the later stages of gene expression, such as the production or degradation of the proteins involved in the resistance, that are affected by the higher temperatures.

The variation in resistance to $B$. cinerea among transgenic plants of the same line could be explained as follows. The transgene copy number was not completely characterized in IVRtomato. Therefore, differential segregation of the transgene could be subject to various levels of RNA silencing; more copies are known to induce gene silencing in an epigenetic process based on a posttranscriptional gene-silencing mechanism (28).

The ability of the IVR gene to induce resistance to Botrytis is one of the very few reported instances in which $\mathrm{R}$ genes that confer resistance to a virus also confer resistance to a fungal pathogen, though genes from bacteria are known to induce resistance to fungi, including $B$. cinerea (15). In a similar situation, a viral R gene cloned from Arabidopsis that confers resistance to Turnip crinkle virus and the yellow mosaic strain of Cucumber mosaic virus also confers resistance to the fungus Peronospora parasitica (3). It will be interesting to see whether transformation of plants with the IVR gene will lead to resistance to other fungal pathogens or nematode pests.

\section{LITERATURE CITED}

1. Akad, F., Teverovsky, E., David, A., Czosnek, H., Gidoni, D., Gera, A., and Loebenstein, G. 1999. A cDNA from tobacco codes for an inhibitor of virus replication (IVR)-like protein. Plant Mol. Biol. 40:969-976.

2. Akad, F., Teverovsky, E., Gidoni, D., Elad, Y., Kirshner, B., Czosnek, H., and Loebenstein, G. 2005. Resistance to Tobacco mosaic virus and Botrytis cinerea in tobacco transformed with the NC330 cDNA encoding an inhibitor of viral replication (IVR)-like protein. Ann. Appl. Biol. 147:89-100.

3. Cooley, M. B., Pathirana, S., Wu, H. J., Kachroo, P., and Klessig, D. F. 2000. Members of the Arabidopsis HRT/RPP family of resistance genes confer resistance to both viral and oomycete pathogens. Plant Cell 12:663-676.

4. Dik, A. J., and Wubben, J. P. 2004. Epidemiology of Botrytis cinerea diseases in greenhouses. Pages 319-333 in: Botrytis: Biology, Pathology and Control. Y. Elad, B. Williamson, P. Tudzynski, and N. Delen, eds. Kluwer Academic Publishers, Dordrecht, The Netherlands.

5. Elad, Y., and Shtienberg, D. 1995. Botrytis cinerea in greenhouse vegetables: Chemical, cultural, physiological and biological controls and their interaction. Integ. Pest Manag. Rev. 1:15-29.

6. Elad, Y., Williamson, B., Tudzynski, P., and Delen, N. 2004. Botrytis spp. and diseases they cause in agricultural systems-An introduction. Pages 1-8 in: Botrytis: Biology, Pathology and Control. Y. Elad, B. Williamson, P. Tudzynski, and N. Delen, eds. Kluwer Academic Publishers, Dordrecht, The Netherlands.

7. Elad, Y., and Yunis, H. 1993. Effect of microclimate and nutrients on development of cucumber gray mold (Botrytis cinerea). Phytoparasitica 21:257-268.

8. Elad, Y., Yunis, H., and Katan, T. 1992. Multiple resistance to benzimidazoles, dicarboximides and diethofencarb in field isolates of Botrytis cinerea in Israel. Plant Pathol. 41:41-46.

9. Elad, Y., Yunis, H., and Mahrer, Y. 1989. The effect of climatic conditions in polyethylene-covered structures on gray mold disease of winter cucumbers. Appl. Agric. Res. 3:243-247.

10. Finkers, R., Van Heusden, A. W., Meijer-Dekens, F., Van Kan, J. A. L., Maris, P., and Lindhout, P. 2007. The construction of a Solanum habrochaites LYC4 introgression line population and the identification of QTLs for resistance to Botrytis cinerea. Theor. Appl. Genet. 114:1071-1100.

11. Gera, A., and Loebenstein, G. 1983. Further studies of an inhibitor of virus replication from tobacco mosaic virus-infected protoplasts of a local lesion-responding cultivar. Phytopathology 73:111-115.

12. Gera, A., Loebenstein, G., Salomon, R., and Franck, A. 1990. An inhibitor of virus replication (IVR) from protoplasts of a hypersensitive tobacco cultivar infected with tobacco mosaic virus is associated with a $23 \mathrm{~K}$ protein species. Phytopathology 80:78-81.

13. Gera, A., Tam, Y., Teverovsky, E., and Loebenstein, G. 1993. Enhanced Tobacco mosaic virus production and suppressed synthesis of the inhibitor of virus replication in protoplasts and plants of local lesion responding cultivars exposed to $35^{\circ} \mathrm{C}$. Physiol. Mol. Plant Pathol. 43:299-306.

14. Guetsky, R., Shtienberg, D., Elad, Y., and Dinoor, A. 2001. Combining biocontrol agents to reduce the variability of biological control. Phytopathology 91:621-627.

15. Jang, Y.-S., Sohn, S.-I., and Wang, M.-H. 2006. The hrpN gene of Erwinia amylovora stimulates tobacco growth and enhances resistance to Botrytis cinerea. Planta 223:449-456.

16. Jarvis, W. R. 1989. Managing diseases in greenhouse crops. Plant Dis. 73:190-194.

17. Kalamaki, M. S., Alexandrou, D., Lazari, D., Merkouropoulos, G., Fotopoulos, V., Pateraki, I., Aggelis, A., Carrillo-Lopez, A., RubioCabetas, M. J., and Kanellis, A. K. 2009. Over-expression of a tomato Nacetyl-L-glutamate synthase gene (SINAGS1) in Arabidopsis thaliana results in high ornithine levels and increased tolerance to salt and drought stresses. J. Exp. Bot. 60:1859-1871.

18. Korolev, N., Mamiev, M., Zahavi, T., and Elad, Y. 2009. Resistance to fungicides among Botrytis cinerea isolates from different hosts in Israel. Acta Hort. 8:367-375.

19. Leroux, P. 2004. Chemical control of Botrytis and its resistance to chemical fungicides. Pages 195-222 in: Botrytis: Biology, Pathology and Control. Y. Elad, P. Williamson, P. Tudzinski, and N. Delen, eds. Kluwer Academic Publishers, Dordrecht, The Netherlands.

20. Loebenstein, G., and Gera, A. 1981. Inhibitor of virus replication released from tobacco mosaic-infected protoplasts of a local lesion-responding tobacco cultivar. Virology 114:32-139.

21. Loebenstein, G., Gera, A., and Gianninazi, S. 1990. Constitutive production of an inhibitor of virus replication in the interspecific hybrid of Nicotiana glutinosa $\times$ Nicotiana debneyi. Physiol. Plant Pathol. 37:145-151.

22. McCormick, S. 1991. Transformation of tomato with Agrobacterium tumefaciens. Pages 1-9 in: Plant Tissue Culture Manual, B6. K. Lindsey, 
ed. Kluwer Academic Publishers, Dordrecht, The Netherlands.

23. Murashige, T., and Skoog, F. 1962. A revised medium for rapid growth and bioassays with tobacco tissue cultures. Physiol. Plant 15:473-497.

24. Nitsch, J. P. 1969. Experimental androgenesis in Nicotiana. Phytomorphology 19:39-404.

25. O’Neill, T. M., Shtienberg, D., and Elad, Y. 1997. Effect of some host and microclimate factors on infection of tomato stems by Botrytis cinerea. Plant Dis. 1:36-40.

26. Sharabani, G., Shtienberg, D., Elad, Y., and Dinoor, A. 1999. Epidemiology of Botrytis cinerea in sweet basil and implications for disease management. Plant Dis. 3:554-560.

27. Spiegel, S., Gera, A., Salomon, R., Ahl, P., Harlap, S., and Loebenstein, G. 1989. Recovery of an inhibitor of virus replication from the intercellular fluid of hypersensitive tobacco infected with Tobacco mosaic virus and from uninfected induced-resistant tissue. Phytopathology 79:25-262.

28. Vaucheret, H., and Fagard, M. 2001. Transcriptional gene silencing in plants: Targets, inducers and regulators. Trends Genet. 17:29-35.

29. Walz, A., Zingen-Sell, I., Loeffler, M., and Sauer, M. 2008. Expression of an oxalate oxidase gene in tomato and severity of disease caused by Botrytis cinerea and Sclerotinia sclerotiorum. Plant Pathol. 57:453-458.

\section{Erratum}

Corrections were made to Table 1 on page 226 and to Table 2 on page 227. Changes to this article were made on February 11, 2010. 